BUDGETING : Journal of Business, Management and Accounting

Volume 1, Nomor 2, Juni 2020

e-ISSN: 2715-2480

p-ISSN: 2715-1913

DOI : https://doi.org/10.31539/budgeting.v1i2.1086

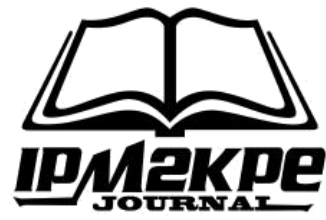

\title{
PENGARUH TOTAL DEBT EQUITY RATIO (DER) DAN TOTAL ASSET TURNOVER (TATO) TERHADAP PROFITABILITAS (ROE) PADA PERUSAHAAN MANUFAKTUR YANG TERDAFTAR DI BURSA EFEK
}

\author{
Rahmi Ambari ${ }^{1}$, Andri Indrawan ${ }^{2}$, Ade Sudarma ${ }^{3}$ \\ Universitas Muhammadiyah Sukabumi ${ }^{1,2,3}$ \\ rahmiambari@yahoo.co.id ${ }^{1}$
}

\begin{abstract}
ABSTRAK
Tujuan dari penelitian ini yaitu untuk mengetahui Pengaruh Total Debt Equity Ratio (DER) dan Total Asset Turnover (TATO) terhadap Profitabilitas (ROE) pada Perusahaan Manufaktur yang terdaftar di BEI. Metode penelitian yang digunakan yaitu kuantitatif, dengan pendekata asosiatif. Teknik pengambilan sampel yang digunakan dalam penelitian ini adalah nonprobability sampling dengan teknik purposive sampling. Teknik analisis data yang digunakan dalam penelitian ini yaitu uji normalitas dan uji parsial (uji t).Hasil dari pengujian secara parsial (uji t) menunjukkan bahwa $t_{\text {hitung }}$ dari variabel Total debt equity ratio (DER) sebesar 1.660 dengan tingkat signifikannya lebih dari 0.05 yaitu sebesar $0.105(0.105>0.05)$, nilai $t_{\text {hitung }}=1.660<\mathrm{t}_{\text {tabel }}=2.014$, maka Ho diterima dan Ha ditolak yang artinya bahwa Total debt equity ratio tidak berpengaruh signifikan terhadap profitabilitas (ROE) dan $t_{\text {hitung }}$ dari variabel Total asset turnover (TATO) sebesar 3.341 dengan tingkat signifikannya kurang dari 0.05 yaitu sebesar $0.002(0.002<0.05)$. Nilai $\mathrm{t}_{\text {hitung }}=3.341>\mathrm{t}_{\text {tabel }}=2.014$, Hasil dari penelitian ini menujukkan bahwa secara parsial hanya total asset turnover yang berpengaruh terhadap profitabilitas (ROE).
\end{abstract}

Kata Kunci: Total Debt Equity Ratio (DER), Total Asset Turnover (TATO), dan Profitabilitas (ROE)

\begin{abstract}
The purpose of this study is to determine the effect of Total Debt Equity Ratio (DER) and Total Asset Turnover (TATO) on Profitability (ROE) in Manufacturing Companies listed on the IDX. The research method used is quantitative, with associative approaches. The sampling technique used in this study was nonprobability sampling with purposive sampling technique. The data analysis technique used in this study is the normality test and partial test ( $t$ test). The results of the partial test ( $t$ test) show that the tcount of variables The total debt equity ratio (DER) is 1.660 with a significant level of more than 0.05, which is 0.105 (0.105>0.05), tcount $=1.660<$ table $=2014$, then Ho is accepted and Ha is rejected, which means that the Total debt equity ratio does not have a significant effect on profitability (ROE) and tcount of the variable Total asset turnover (TATO) of 3,341 with a significant level of less than 0.05 which is 0.002 (0.002 <0.05). Tcount $=3,341>t$ table $=2014$. The results of this study show that partially only total asset turnover has an effect on profitability (ROE).
\end{abstract}

Keywords : Total Debt Equity Ratio (DER), Total Asset Turnover (TATO), Return on Equity (ROE) 


\section{PENDAHULUAN}

Pertumbuhan bisnis dan usaha khususnya perusahaan manufaktur di Indonesia yang semakin besar menimbulkan banyaknya persaingan terutama pada perusahaan yang sejenis, tuntutan dari perusahaan sejenis ini sehingga memerlukan pengamatan dan penelitian serta penilaian untuk melihat perkembangan dan peningkatan dalam kinerjanya.

Persaingan yang semakin ketat menuntut perusahaan untuk membuat strategi pelaksanaan kegiatan yang efektif dan efisien agar dapat mencapai tujuan yang telah ditetapkan. Tujuan dari perusahaan tersebut yaitu untuk meningkatkan laba. Untuk mencapai tujuan yang telah ditetapkan, maka perusahaan harus mengadakan evaluasi untuk meninjau kinerja perusahaan dalam segi profitabilitas di setiap periode. Agus (2010) menyatakan bahwa profitabilitas merupakan kemampuan perusahaan memperoleh dalam hubungannya dengan penjualan, total aktiva maupun modal sendiri. Profitabilitas yang digunakan dalam penelitian ini adalah Return On Equity (ROE). Fahmi (2011) menyatakan bahwa "ROE dapat disebut juga dengan laba atas equity."

Kinerja keuangan dan laba termasuk ke dalam laporan keuangan. Fahmi (2011) menyatakan bahwa laporan keuangan merupakan suatu informasi yang menggambarkan kondisi keuangan suatu perusahaan, dan lebih jauh informasi tersebut dapat dijadikan sebagai gambaran kinerja keuangan perusahaan tersebut. Dapat disimpulkan, laporan keuangan merupakan laporan yang menunjukkan kondisi keuangan perusahaan pada saat ini atau dalam suatu periode tertentu yang dapat menggambarkan kinerja keuangan perusahaan. Sehingga apabila perusahaan memiliki kinerja keuangan yang baik, maka laba perusahaan akan ikut meningkat. Sebaliknya jika perusahaan memiliki kinerja keuangan yang tidak baik, maka laba akan ikut menurun. Oleh karena itu, laba merupakan suatu keuntungan yang dihasilkan oleh suatu perusahaan disetiap tahunnya. Suatu laporan keuangan digunakan untuk mengukur naik atau turunnya laba perusahaan yaitu dengan menggunakan rasio-rasio keuangan. Rasio-rasio keuangan yang akan digunakan dalam penelitian ini yaitu Rasio Leverage dan Rasio Aktivitas sebagai variabel independen yang akan dilihat pengaruhnya terhadap Profitabilitas.

Harahap (2016) menyebutkan bahwa Rasio Leverage menggambarkan hubungan antara utang perusahaan terhadap modal maupun asset. Rasio ini dapat melihat seberapa jauh perusahaan dibiayai oleh utang atau pihak luar dengan kemampuan perusahaan 
yang digambarkan oleh modal (equity). Dari banyaknya rasio leverage, rasio yang akan digunakan dalam penelitian ini yaitu Total Debt To Equity Ratio (DER).

Fahmi (2011) Rasio aktivitas adalah rasio yang menggambarkan sejauh mana suatu perusahaan mempergunakan sumber daya yang dimilikinya guna menunjang aktivitas perusahaan, dimana penggunaan aktivitas ini dilakukan secara sangat maksimal dengan maksud memperoleh hasil yang maksimal. Dari banyaknya rasio aktivitas, rasio yang akan digunakan dalam penelitian ini yaitu Total Asset Turnover (TATO).

\section{KAJIAN TEORI}

\section{Tujuan dan manfaat Rasio Leverage}

Kasmir (2015) mengemukakan tujuan perusahaan dengan menggunakan rasio leverage yaitu:

1. Untuk mengetahui posisi perusahaan terhadap kewajiban kepada pihak lainnya (kreditor).

2. Untuk menilai kemapuan perusahaan dalam memenuhi kewajiban yang bersifat tetap (seperti angsuran pinjaman termasuk bunga).

3. Untuk menilai keseimbangan antara nilai aktiva khususnya aktiva tetap dengan modal.

4. Untuk menilai seberapa besar aktiva perusahaan dibiayai oleh utang.

5. Untuk menilai seberapa besar pengaruh utang perusahaan terhadap pengelolaan aktiva.

6. Untuk menilai atau mengukur berapa bagian dari setiap rupiah modal sendiri yang dijadikan jaminan utang jangka panjang.

7. Untuk menilai berapa dana pinjaman yang akan segera ditagih, terdapat sekian kalinya modal sendiri yang dimiliki.

Kasmir (2015) mengemukakan manfaat perusahaan dengan menggunakan rasio leverage yaitu:

1. Untuk menganalisis kemampuan posisi perusahaan terhadap kewajiban kepada pihak lainnya.

2. Untuk menganalisis kemampuan perusahaan memenuhi kewajiban yang bersifat tetap (seperti angsuran pinjaman termasuk bunga). 
3. Untuk menganalisis keseimbangan antara nilai aktiva khususnya aktiva tetap dengan modal.

4. Untuk menganalisis seberapa besar aktiva perusahaan dibiayai oleh utang.

5. Untuk menganalisis seberapa besar utang perusahaan berpengaruh terhadap pengelolaan aktiva.

6. Untuk menganalisis atau mengukur berapa bagian dari setiap rupiah modal sendiri yang dijadikan jaminan utang jangka panjang.

7. Untuk menganalisis berapa dana pinjaman yang segera akan ditagih ada terdapat sekian kalinya modal sendiri.

\section{Pengukuran Rasio Leverage}

Salah satu pengukuran rasio leverage yang digunakan oleh peneliti dalam penelitian ini yaitu total debt to equity ratio (DER). Murhadi (2013) Debt to equity ratio menunjukkan perbandingan antara utang dan ekuitas perusahaan. Bagi suatu perusahaan semakin besar rasio ini maka semakin besar pula beban perusahaan tersebut terhadap pihak luar, hal ini memungkinkan dapat menurunkan kinerja perusahaan, karena tingkat ketergantungan kepada pihak luar tersebut semakin tinggi. Berikut rumus untuk menghitung DER yaitu:

$$
D E R=\frac{\text { Total Debt }}{\text { Total Equity }}
$$

\section{Tujuan dan Manfaat Rasio Aktivitas}

Kasmir (2015) mengemukakan tujuan perusahaan dengan menggunakan rasio aktivitas yaitu:

1. Untuk mengukur berapa lama penagihan piutang selama satu periode atau berapa kali dana yang ditanam dalam piutang ini berputar dalam satu periode.

2. Untuk menghitung hari rata-rata penagihan piutang (days of receivable), di mana hasil perhitungan ini menunjukkan jumlah hari (berapa hari) piutang tersebut ratarata tidak dapat ditagih.

3. Untuk menghitung berapa hari rata-rata sediaan tersimpan dalam gudang. 
4. Untuk mengukur berapa kali dana yang ditanamkan dalam modal kerja berputar dalam satu periode atau berapa penjualan yang dapat dicapai oleh setiap modal kerja yang digunakan (working capital turn over).

5. Untuk mengukur berapa kali dana yang ditanamkan dalam aktiva tetap berputar dalam satu periode.

6. Untuk mengukur penggunaan semua aktiva perusahaan dibandingkan denngan penjualan.

Kasmir (2015) mengemukakan tujuan perusahaan dengan menggunakan rasio profitabilitas yaitu:

1. Dalam bidang piutang

a. Perusahaan atau manajemen dapat mengetahui berapa lama piutang mampu ditagih selama satu periode. Kemudian, manajemen juga dapat mengetahui berapa kali dana yang ditanam dalam piutang ini berputar dalam satu periode. Dengan demikan, dapat diketahui efektif atau tidaknya kegiatan perusahaan dalam bidang penagihan.

b. Manajemen dapat mengetahui jumlah hari dalam rata-rata penagihan piutang (days of receivable) sehingga manajemen dapat pula mengetahui jumlah hari (berapa hari) piutang tersebut rata-rata tidak dapat ditagih.

2. Dalam bidang sediaan

Manajemen dapat mengetahui hari rata-rata sediaan tersimpan dalam gudang. Hasil ini dibandingkan dengan target yang telah ditentukan atau rata-rata industry. Kemudian perusahaan dapat pula membandingkan hasil ini dengan pengukuran rasio beberapa periode yang lalu.

3. Dalam bidang modal kerja dan penjualan

a. Manajemen dapat mengetahui berapa kali dana yang ditanamkan dalam aktiva tetap berputar dalam satu periode.

b. Manajemen dapat mengetahui penggunaan semua aktiva perusahaan dibandingkan dengan penjualan dalam satu periode tertentu.

\section{Pengukuran Rasio Aktivitas}

Salah satu pengukuran rasio likuiditas yang digunakan oleh peneliti dalam penelitian ini yaitu total asset turnover (TATO). Harahap (2016) Total Asset Turnover 
merupakan perputaran total aktiva diukur dari volume penjualan dengan kata lain seberapa jauh kemampuan semua aktiva menciptakan penjualan. Maka dapat disimpulkan bahwa semakin tinggi rasio TATO maka semakin baik perputaran aktiva perusahaan untuk mendapatkan laba, sebaliknya semakin rendah rasio TATO maka semakin lambat perputaran aktiva perusahaan dalam memperoleh laba. Berikut rumus untuk menghitung rasio TATO yaitu:

$$
\text { TATO }=\frac{\text { Sales }}{\text { Total Asset }}
$$

\section{Tujuan dan Manfaat Rasio Profitabilitas}

Kasmir (2015) mengemukakan tujuan perusahaan dengan menggunakan rasio profitabilitas yaitu:

1. Untuk mengukur atau menghitung laba yang diperoleh perusahaan dalam satu periode tertentu.

2. Untuk menilai posisi laba perusahaan tahun sebelumnya dengan tahun sekarang.

3. Untuk menilai perkembangan laba dari waktu ke waktu.

4. Untuk menilai besarnya laba bersih sesudah pajak dengan modal sendiri.

5. Untuk mengukur produktivitas seluruh dana perusahaan yang digunakan baik modal pinjaman maupun modal sendiri.

6. Untuk mengukur produktivitas dari seluruh dana perusahaan yang digunakan baik modal sendiri.

Kasmir (2015) mengemukakan manfaat perusahaan dengan menggunakan rasio profitabilitas yaitu:

1. Mengetahui besarnya tingkat laba yang diperoleh perusahaan dalam satu periode.

2. Mengetahui posisi laba perusahaan tahun sebelumnya dengan tahun sekarang.

3. Mengetahui perkembangan laba dari waktu ke waktu.

4. Mengehaui besarnya laba bersih sesudah pajak dengan modal sendiri.

5. Mengetahui produktivitas dari seluruh dana perusahaan yang digunakan baik modal pinjaman maupun modal sendiri. 


\section{Pengukuran Rasio Profitabilitas}

Salah satu pengukuran rasio profitabilitas yang digunakan oleh peneliti dalam penelitian ini yaitu hasil pengembalian ekuitas atau return on equity (ROE). Rasio ini digunakan untuk mengukur tingkat laba bersih setelah pajak dengan menggunakan modal sendiri. Dapat disimpulkan bahwa semakin tinggi ROE, maka semakin baik, yang artinya semakin kuat posisi pemilik perusahaan maka akan semakin baik, demikian pula sebaliknya. Berikut rumus untuk menghitung ROE yaitu:

$$
R O E=\frac{\text { Earning After } \operatorname{Tax}(E A T)}{\text { Shareholders'Equity }}
$$

\section{METODE PENELITIAN}

Variabel dalam penelitian ini terdiri dari variabel independen yaitu Debt Equity Ratio $\left(\mathrm{X}_{1}\right)$ dan Total Asset Turnover $\left(\mathrm{X}_{2}\right)$ serta variabel dependen Profitabilitas $(\mathrm{Y})$. Penelitian ini menggunakan metode kuantitatif dengan pendekatan asosiatif. Teknik pengumpulan data yang digunakan dalam penelitian ini yaitu dengan menggunakan data sekunder.

Adapun populasi dalam penelitian ini yaitu Laporan Keuangan Perusahaan Manufaktur yang terdaftar di Bursa Efek Indonesia, dengan jumlah sampel sebanyak 70 laporan keuangan pertahun atau data yang dianalisis selama 7 tahun dari tahun 20122018. Teknik pengambilan sampel yang digunakan peneliti adalah nonprobability sampling dengan teknik purposive sampling, dimana sampel tersebut dipilih dengan pertimbangan dan kriteria tertentu yang telah ditentukan. Penelitian ini menggunakan Uji Normalitas data dan Uji Hipotesis Parsial (uji t).

\section{HASIL PENELITIAN}

\section{Pengaruh Total Debt Equity Ratio (DER) secara Parsial terhadap Profitabilitas (ROE)}

Hasil penelitian dengan menggunakan uji t (parsial) menunjukkan bahwa $t_{\text {hitung }}$ dari variabel Total debt equity ratio sebesar 1.660 dengan tingkat signifikannya lebih dari 0.05 yaitu sebesar 0.105 . Nilai $t_{\text {hitung }}=1.660<t_{\text {tabel }}=2.014$, maka Ho diterima dan Ha ditolak yang artinya bahwa Total debt equity ratio tidak berpengaruh signifikan terhadap profitabilitas (ROE) perusahaan dan tingkat signifikannya $0.105>0.05$, 
menunjukkan pengaruh yang tidak signifikan. Maka dapat disimpulkan bahwa Total debt equity ratio tidak berpengaruh signifikan terhadap profitabilitas (ROE) perusahaan pada perusahaan sektor manufaktur yang terdaftar di Bursa Efek Indonesia periode 2012-2018.

\section{Pengaruh Total Asset Turnover (TATO) secara Parsial terhadap Profitabilitas (ROE)}

Hasil penelitian dengan menggunakan uji t (parsial) menunjukkan bahwa $t_{\text {hitung }}$ dari variabel Total asset turnover sebesar 3.341 dengan tingkat signifikannya kurang dari 0.05 yaitu sebesar 0.002. Nilai $\mathrm{t}_{\text {hitung }}=3.341>\mathrm{t}_{\text {tabel }}=2.014$, maka Ho ditolak dan Ha diterima yang artinya bahwa Total asset turnover berpengaruh signifikan terhadap profitabilitas $(\mathrm{ROE})$ perusahaan dan tingkat signifikannya $0.002<0.05$, menunjukkan pengaruh yang signifikan. Maka dapat disimpulkan bahwa Total asset turnover berpengaruh signifikan terhadap profitabilitas (ROE) perusahaan pada perusahaan sektor manufaktur yang terdaftar di Bursa Efek Indonesia periode 2012-2018.

\section{PEMBAHASAN}

\section{Pengaruh Total Debt Equity Ratio (DER) secara Parsial terhadap Profitabilitas (ROE)}

Hasil penelitian dengan menggunakan uji t (parsial) menunjukkan bahwa $t_{\text {hitung }}$ dari variabel Total debt equity ratio sebesar 1.660 dengan tingkat signifikannya lebih dari 0.05 yaitu sebesar 0.105 . Nilai $\mathrm{t}_{\text {hitung }}=1.660<\mathrm{t}_{\text {tabel }}=2.014$, maka Ho diterima dan Ha ditolak yang artinya bahwa Total debt equity ratio tidak berpengaruh signifikan terhadap profitabilitas (ROE) perusahaan dan tingkat signifikannya $0.105>0.05$, menunjukkan pengaruh yang tidak signifikan. Maka dapat disimpulkan bahwa Total debt equity ratio tidak berpengaruh signifikan terhadap profitabilitas (ROE) perusahaan pada perusahaan sektor manufaktur yang terdaftar di Bursa Efek Indonesia periode 2012-2018.

Penelitian ini sejalan dengan penelitian yang dilakukan oleh Yulsiati (2016) hasil penelitian tersebut menunjukkan bahwa variabel Debt Equity Ratio (DER) tidak berpengaruh terhadap Return On Equity (ROE). Hutang memiliki dampak yang tidak baik terhadap kinerja perusahaan yang akan mempengaruhi laba perusahaan, karena perusahaan yang memiliki tingkat hutang yang tinggi dapat menyebabkan beban bunga 
bertambah atau semakin besar, dan besarnya beban bunga yang akan ditanggung perusahaan tersebut bisa menurunkan jumlah laba yang akan diterima perusahan tersebut. Hasil penelitian ini didukung teori yang dikemukakan oleh Murhadi (2013) yang menyatakan bahwa "semakin rendah DER maka akan semakin baik suatu perusahaan dalam memaksimumkan profitabilitasnya."

\section{Pengaruh Total Asset Turnover (TATO) secara Parsial terhadap Profitabilitas (ROE)}

Hasil penelitian dengan menggunakan uji t (parsial) menunjukkan bahwa $t_{\text {hitung }}$ dari variabel Total asset turnover sebesar 3.341 dengan tingkat signifikannya kurang dari 0.05 yaitu sebesar 0.002. Nilai $\mathrm{t}_{\text {hitung }}=3.341>\mathrm{t}_{\text {tabel }}=2.014$, maka Ho ditolak dan Ha diterima yang artinya bahwa Total asset turnover berpengaruh signifikan terhadap profitabilitas $(\mathrm{ROE})$ perusahaan dan tingkat signifikannya $0.002<0.05$, menunjukkan pengaruh yang signifikan. Maka dapat disimpulkan bahwa Total asset turnover berpengaruh signifikan terhadap profitabilitas (ROE) perusahaan pada perusahaan sektor manufaktur yang terdaftar di Bursa Efek Indonesia periode 2012-2018.

Penelitian ini sejalan dengan penelitian yang dilakukan oleh Kartikaningsih (2013) hasil penelitian tersebut menujukkan bahawa variabel Total Asset Turnover berpengaruh signifikan terhadap Return On Equity. Hasil penelitian ini juga didukung teori yang dikemukakan oleh Harahap (2016) menyatakan bahwa semakin tinggi rasio TATO maka semakin baik perputaran aktiva perusahaan untuk mendapatkan laba, sebaliknya semakin rendah rasio TATO maka semakin lambat perputaran aktiva perusahaan dalam memperoleh laba.

\section{SIMPULAN}

DER tidak berpengaruh signifikan terhadap profitabilitas (ROE) perusahaan secara parsial. Sehingga dapat disimpulkan bahwa hasil penelitian ini sesuai dengan hipotesis. TATO berpengaruh signifikan terhadap profitabilitas (ROE) perusahaan secara parsial. Sehingga dapat disimpulkan bahwa hasil penelitian ini sesuai dengan hipotesis. 


\section{DAFTAR PUSTAKA}

Agus, R., S. (2010). Manajemen Keuangan Teori dan Aplikasi. Edisi Keempat. Yogyakarta: BPFE.

Fahmi, I. (2011). Analisa Laporan Keuangan. Bandung: Alfabeta.

Harahap, S., S. (2016). Analisis Kritis Atas Laporan Keuangan.Cetakan Ke-13, Jakarta: Rajawali Pers.

Kartikaningsih, D. (2013). Pengaruh Debt Rasio, Current Rasio, Total Assets Turnover, Size Perushaan, dan Net Profit Margin Terhadap Return On Equity (Studi Kasus pada Perushaan Manufaktur yang Terdaftar di Bursa Efek Indonesia pada Tahun 2009-2011). Jurnal Akuntansi, Program studi Akuntansi, Fakultas Ekonomi, Universitas Sarjanawiyata Tamansiswa Yogyakarta.

Kasmir, (2015). Analisa Laporan Keuangan. Cetakan Ke-8, Jakarta: Rajawali Pers.

Murhadi, W., R. (2013). Analisa Laporan Keuangan Proyeksi dan Valuasi Saham. Jakarta: Salemba Empat.

Yulsiati, H. (2016). Pengaruh Debt To Assets Ratio, Debt To Equity Ratio dan Net Profit Margin Terhadap Return On Equity Pada Perusahaan Property dan Real Estate yang Terdaftar Di Bursa Efek Indonesia. Jurnal Akuntanika, Politeknik Negeri Sriwijaya. 